L. Ocorrência de dois casos autóctones de leishmaniose tegumentar americana no bairro do Caju, Município do Rio de Janeiro, Brasil. An Bras Dermatol. 2014;89:848-50

3. Benício E, Cordeiro M, Monteiro H, Saboia Moura MA, Oliveira C, Nunes Gadelha $\mathrm{EP}$, et al. Sustained presence of leishmaniasis in urban Manaus, the largest human settlement in the Amazon. Am J Trop Med Hyg. 2015;93:1208-13.

4. Souza CF. Estudo da leishmaniose tegumentar americana na região urbana do Município de Timóteo e no Parque Estadual do Rio Doce, Minas Gerais, Brasil [tese]. Rio de Janeiro (RJ): Instituto Oswaldo Cruz; 2015. 107 p.

5. Silva ANM, Santos TV, Silva FBB, Lima JAN, Santos LAS, Ramos PKS, et al. Leishmaniose tegumentar americana na região metropolitana de Belém, Pará Brasil: fragmentação florestal urbana não impede manutenção do ciclo enzoótico de Leishmania (L.) amazonenses. In: Anais do 52. Congresso da Sociedade Brasileira de Medicina Tropical; 2016 ago 21-24; Maceió, Brasil. Maceió: Medtrop; 2016. [acesso 25 set 2017]. Disponivel em: http://www.sbmt.org.br/ medtrop2016/wp-content/uploads/2016/10/10473-Leishmaniose-tegumentarAmericana-na-Regia\%CC\%830-Metropolitana-de-Bele\%CC\%81m...p

How to cite this article: Carneiro FRO, Amin GA, Cruz LBP, Daher BA. Urban American cutaneous leishmaniasis. An Bras Dermatol. 2018;93(1):156-8

\section{$\sqrt{ }$}

\section{Topical corticosteroid therapy: a treatment option for nevus lipomatosus cutaneous superficialis?*}

\author{
Rafaella Daboit Castagna \\ Lia Natália Diehl Dallazem² \\ Ana Maria Benvegnú ${ }^{2}$ \\ Catiussa Spode Brutti ${ }^{3}$
}

DOI: http:/ / dx.doi.org/10.1590/abd1806-4841.20186986

\section{Dear editor,}

The nevus lipomatosus cutaneous superficialis (NLCS) is a rare benign hamartomatous tumor. ${ }^{1-3}$ It presents in two clinical forms: the classic and the solitary. The classic form usually occurs in

Received on 30.01.2017.

Approved by the Advisory Board and accepted for publication on 22.05.2017

* Study conducted at Hospital Universitário de Santa Maria, Universidade Federal de Santa Maria (HUSM-UFSM) - Santa Maria (RS), Brazil.

Financial support: None.

Conflict of interests: None.

1 Private Practice - Lages (SC), Brazil

Department of Internal Medicine, Universidade Federal de Santa Maria (UFSM) - Santa Maria (RS), Brazil.

Department of Dermatology, Hospital Universitário de Santa Maria, Universidade Federal de Santa Maria (HUSM-UFSM) - Santa Maria (RS), Brazil.

MAILING ADDRESS:

Rafaella Daboit Castagna

E-mail: lellacastagna@hotmail.com

C2018 by Anais Brasileiros de Dermatologia

(cc) BY-NC childhood and adolescence and is characterized by multiple asymptomatic, soft, cerebriform, pedunculated, yellow or skin-colored papules, nodules or plaques. ${ }^{3}$ The solitary form is uncommon and usually affects individuals older than 20 years of age; it presents as a single sessile papule or dome-shaped lesion. ${ }^{1}$

The treatment option is usually motivated by cosmetic purposes, because there are no systemic consequences nor associated malignant tumors. Surgical excision is an appropriate option if the patient decides to treat. ${ }^{1,4}$ We report an unusual case of classic NLCS, with onset in an atypical age group that had satisfactory clinical response with topical corticosteroid treatment.

Female, 52-year-old patient, smoker, presented with the lesion on the back for almost 2 years. In hot days and with sun exposure, the lesion became itchy with development of erythema and edema. Physical examination revealed a yellow plaque formed by multiple pedunculated and confluent papules, measuring $7 \mathrm{~cm}$ $x 10 \mathrm{~cm}$, on the right infrascapular region, following the Blaschko's lines, not crossing the median line (Figure 1). Darier sign was negative. Initial differential diagnosis were solitary mastocytoma, neurofibroma, cutaneous leiomyoma and Shagreen patch. A punch n. ${ }^{\circ} 4$ biopsy was performed and the histopathology revealed mast cells in the subtle superficial and interstitial perivascular inflammatory infiltrate, suggestive of cutaneous mastocytosis. We prescribed fludroxycortide $(0.125 \mathrm{mg} / \mathrm{g})$ cream whenever the lesion became itchy. The patient used the medication almost daily for four months, with improvement of the symptoms and partial involution of the lesion (Figure 2). Despite worsening with heat and sun exposure, the clinical aspect and the course of the lesion were not typical of cutaneous mastocytosis, so we suspected NLCS. A new incisional biopsy was performed (ellipse) and the histopathology revealed mature fax tissue in the dermis, more prominent around the vessels and associated to dermal perivascular and interstitial mast cells - findings there are consistent with NLCS (Figure 3). We opted not to perform surgery due to the regression of the lesion with topical corticosteroid treatment and the lack of symptoms.

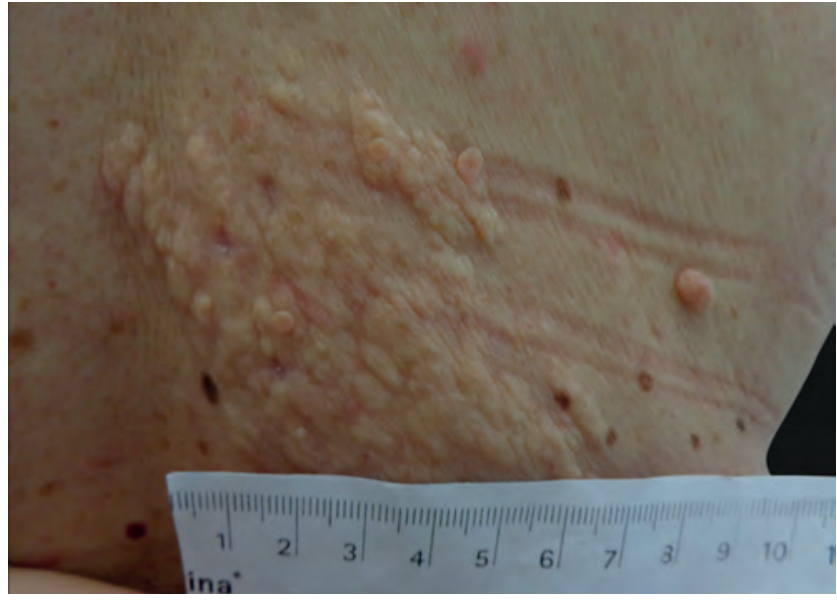

FIGURE 1: Subtly yellow plaque, made by multiple pedunculated and confluent papules on the right infrascapular region 
NLCS was first described by Hoffmann and Zurhelle in $1921 .{ }^{1}$ It is a benign and idiopathic malformation, characterized by the presence of mature ectopic fat tissue among the collagen bundles in the dermis. ${ }^{4}$ Familial occurrence was not seen, and neither was gender predilection or association with other systemic conditions. ${ }^{2}$

There are two forms of NLCS: the classical form, described by Hoffmann and Zurhelle, and the soliand the solitary form, both with chronic and asymptomatic course. ${ }^{1,4}$ In the classical form, multiple papules are seen, coalescing into plaques, with a zosteriform, linear or segmental distribution. They are skin colored or yellow, soft or with a cerebriform surface, and can reach large dimensions. They are located on the upper thighs, buttocks and on the lumbar region, are usually unilateral and are present at birth or in the first 2 decades of life. ${ }^{2,3,5}$ The solitary form arises from 30 to 50 years of age and is characterized by an isolated sessile or dome-shaped papule on any part of the body surface, but predominantly on the lower trunk, knees, axillae, upper limbs, earlobes and scalp. ${ }^{4}$

The diagnosis is based on the clinical suspicion and confirmation by histopathology. The histopathology reveals mature ectopic adipocytes interspersed with collagen bundles and prolifer-

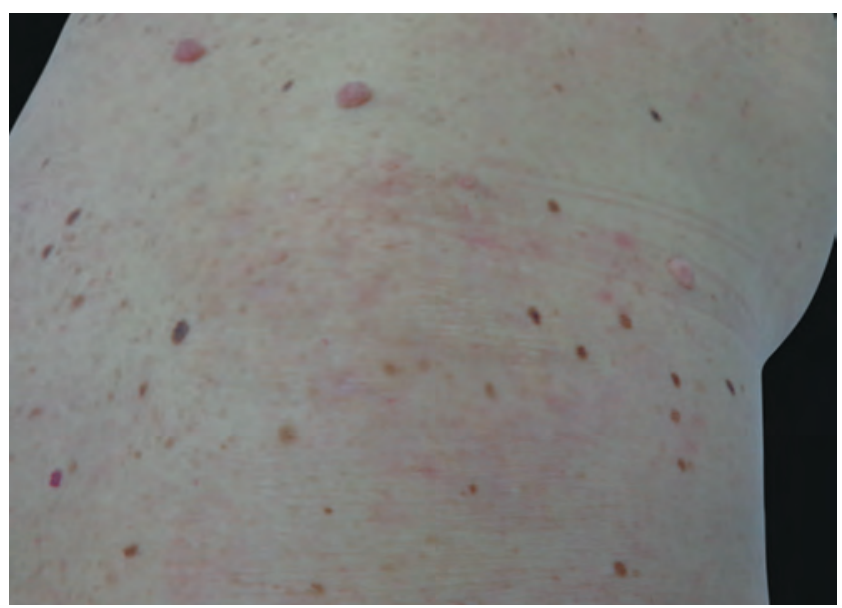

Figure 2: Clinical improvement after 4 months of topical corticotherapy

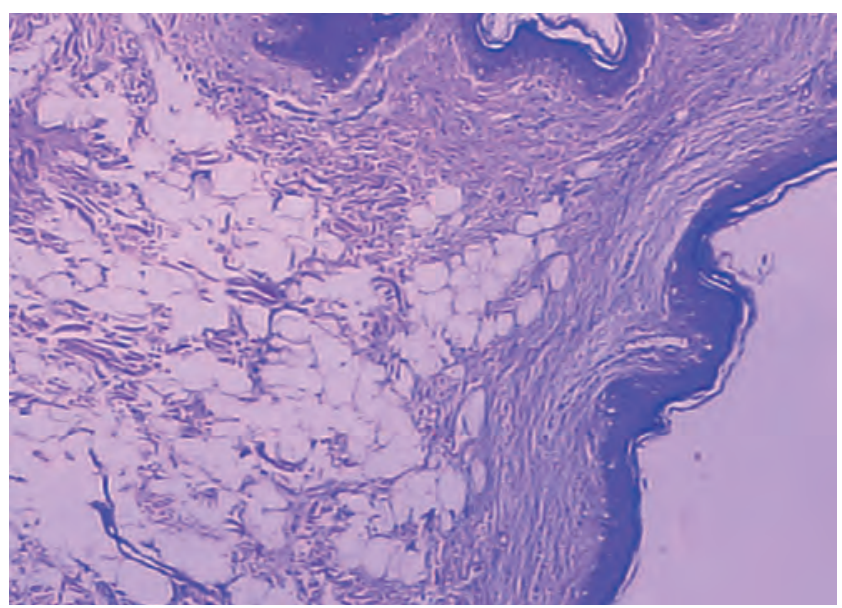

Figure 3: Mature fat tissue in the dermis, more prominent around the vessels and associated to the presence of perivascular and interstitial dermal mast cells (Hematoxylin \& eosin, X40) ating around the periadnexal adventitious dermis and perivascular area. The mature adipocytes proliferate in the reticular dermis and extend to the papillary dermis, without connecting to the subcutaneous fat tissue. ${ }^{2}$ When there is extensive ectopic build-up of the mature adipocytes in the dermis, the area between the end of the dermis and beginning of the subcutaneous tissue is not clear. Therefore, a larger sample of tissue was paramount in allowing a more precise demarcation by the pathologist.

Treatment is essentially aesthetic and surgical excision is an adequate option. ${ }^{1}$ Non-surgical treatment options include cryotherapy, $\mathrm{CO}_{2}$ ablative laser and intralesional injections of phosphatidylcholine and sodium deoxycholate, with satisfactory clinical and histologic response. ${ }^{2,3}$

We report a case of classic NLCS that developed in the $5^{\text {th }}$ decade of life - unusual age group - , that evolved with pruritus, contrary to the commonly asymptomatic course of the lesion. There is no report of the use of topical corticosteroids for the treatment of NLCS in the literature. In the case reported, the lesion improved significantly from the symptoms and clinical aspect after using fludroxycortide.

The case reported brings a new conception in regards to the use of topical corticotherapy for NLCS cases, that needs more clarification, but that elicits the possibility of a new safe, effective and non-invasive treatment, that can be particularly useful for large lesions. $\square$

\section{REFERENCES}

1. Dudani S, Malik A, Mani NS.Nevus Lipomatosis Cutaneous Superficialis A clinicopathologic study of the solitary type. Med J Armed Forces India. 2016;72:67-70

2. Goucha S, Khaled A, Zéglaoui F, Rammeh S, Zermani R, Fazaa B. Nevus Lipomatosus Cutaneous Superficialis: Report of Eight Cases. Dermatol Ther (Heidelb). 2011;1:25-30.

3. Kim HS, Park YM, Kim HO, Lee JY. Intralesional phosphatidylcholine and sodium deoxycholate: a possible treatment option for nevus lipomatosus superficialis. Pediatr Dermatol. 2012;29:119-21.

4. Pujani M, Choudhury M, Garg T, Madan NK. Nevus lipomatosus superficialis: A rare cutaneous hamartoma. Indian Dermatol Online J. 2014;5:109-10.

5. Jung ST, Park HW, Yun SJ. Giant nevus lipomatosus cutaneous superficialis with intramuscular lipomatosis. J Am Acad Dermatol. 2012;67:e168-70.

How to cite this article: Castagna RD, Benvegnú AM, Dallazem LND, Brutti CS. Topical corticosteroid therapy: a treatment option for nevus lipomatosus cutaneous superficialis? An Bras Dermatol. 2018;93(1):158-9. 